\title{
Estimates of combining ability and standard heterosis for grain yield and various agromorphological traits in rice (Oryza sativa L.)
}

\author{
Gaurav Kamboj ${ }^{1}$, Pradeep Kumar ${ }^{* 2}$ and Devi Singh ${ }^{1}$ \\ ${ }^{1}$ Sardar Vallabhbhai Patel University of Agriculture and Technology, Meerut- 250110 (UP), INDIA \\ ${ }^{2}$ Indian Institute of Wheat and Barley Research, Karnal- 132001 (Haryana), INDIA \\ *Corresponding author. E-mail: pradeeptaliyan231@gmail.com
}

Received: May 14, 2016; Revised received: October 25, 2016; Accepted: February 19, 2017

\begin{abstract}
A study was conducted for estimating combining ability and standard heterosis for grain yield and various agromorphological traits involving 10 parents and their $45 \mathrm{~F}_{1} \mathrm{~s}$ (half diallel) during 2012-13 and 2013-14. The results of present investigation revealed that additive gene action played a predominant role in the inheritance of most of the traits under study. On the basis of general combining ability (GCA) effects and specific combining ability (SCA) effects, three parents (Vallabh Basmati 21, Pusa Basmati 1, CSR 13) and three crosses (Vallabh Basmati 21 x Pusa 1121, Pusa 1121 x CSR 13 and Pusa Basmati 1 x CSR 13) were found good general and specific combiners. The best combinations mostly involved good $x$ good and good $x$ poor parental GCA effects suggesting that there is additive $x$ additive and additive $x$ dominance type of gene action for yield and other component traits. The cross showing additive gene action can be improved by pedigree breeding and selection can be postponed to later generations. The most appropriate breeding method for the exploitation of non additive gene action will be heterosis breeding. The six best cross combinations (Vallabh Basmati 21 x CSR 30, CSR 30 x CSR 13, Vallabh Basmati 21 x CSR 13, CSR 30 x Pusa basmati 1, Pusa basmati 1 x CSR 13 and Vallabh Basmati 21 x Pusa basmati 1) had significant standard heterosis for grain yield and other component traits. The crosses which showed significant standard heterosis is highly suitable for commercial exploitation of heterosis in rice crop.
\end{abstract}

Keywords: GCA, SCA, Diallel analysis, Gene effect, Rice, Standard heterosis

\section{INTRODUCTION}

India is the second largest producer and consumer of rice in the world after China. At national level, the area under rice cultivation is 42.5 million hectares with the production of 152.6 million tones and an average productivity is of 3.5 tones/hectares. At global level, rice is cultivated under 158.4 million hectares area with an annual production of around 697.2 million tones and an average productivity of 2.85 tones/ hectares (Sarvan et al. 2016). In designing an efficient breeding programme, the breeder faces a major problem of choosing parents for hybridization. Knowledge of the genetic system, controlling yield and its contributing traits, is thus useful in understanding the genetic architecture of parents and thus help to select parents possessing a good genetic potential. The combining ability analysis provides useful information about the nature and magnitude of gene action and selection of suitable parents and cross combination to proposed a systematic and effective breeding programme and to utilize them in further breeding programme for the improvement in the yield potential of a crop. The general combining ability give the information about additive and additive $\mathrm{x}$ additive gene action, whereas specific combining ability about the non-allelic interaction and dominance gene action. The knowledge of general combining ability and specific combining ability effects with their variance determines the ability of parents and crosses for involving them in an effective breeding programme. The major objective of a breeder is to create the genetic variability to select the superior breeding material and to develop the genotypes with high yield potential under any cross breeding programme. But before doing this, it is necessary to have sufficient information about the genetic architecture of yield and its component traits because yield and yield contributing traits are polygenic in nature and are influenced by the environmental factors. To know about genetic architecture of these traits, several biometrical techniques are available. Each of them has its own merits and demerits but these techniques give the information about nature and magnitude of gene action and there by selection of suitable parents and cross combinations for the maximum exploitation of available genetic variability and formulation of suitable breeding programme towards crop improvement. Diallel cross technique developed and illustrated by Hayman (1954a) provides information in early generations on genetic mechanism involved in character expression. Since local genotypes had valuable genes for many quantitative traits such as grain yield, 1000 
grain weight, plant height, number of grains per panicle, number of branches per plant, biological yield, spike length and productive tillers per plant, therefore the present investigation was undertaken to identify the best general and specific combiners, best heterotic cross combinations and to know about the genetic mechanism involved in the inheritance of grain yield and agro-morphological traits using diallel method excluding reciprocals is considered to be most suitable because it gives maximum information related to genetic analysis and other parameters for formulation of suitable breeding strategies which may be helpful in the improvement of rice genotypes.

\section{MATERIALS AND METHODS}

The base material consists 10 diverse genotypes of rice (Vallabh Basmati 21, Vallabh Basmati 22, MAUB 57, Pusa 1121, CSR 30, Pusa Basmati 1, Basmati 370, Pusa 1401, CSR 13 and CSR 10) was planted at Crop Research Centre, SVBPU\&T, Meerut during rabi 2011 -2012 for attempting crossing in a 10x10 diallel fasion excluding reciprocals. In the next crop season (i.e. rabi 2012-2013), experimental material consisted total 55 genotypes (10 parents and their $\left.45 \mathrm{~F}_{1} \mathrm{~s}\right)$ was sown in a randomized block design with three replications. All the standard agronomical practices were followed to raise normal crop. Observations were recorded on five randomly selected plants from each genotype (Parents and $F_{1} s$ ) in each replication and the mean value was used for statistical analysis. Observation were recorded on days to $50 \%$ flowering, days to maturity, plant height $(\mathrm{cm})$, panicle length $(\mathrm{cm})$, number of productive tillers per plant, number of branches per panicle, number of grains per panicle, flag leaf area $\left(\mathrm{cm}^{2}\right), 1000$ grain weight $(\mathrm{g})$, biological yield per plant $(\mathrm{g})$, grain yield per plant $(\mathrm{g})$, harvest index $(\%)$. Analyses of variance were estimated following the method suggested by Panse and Sukhatme (1967). For flag leaf area $\left(\mathrm{cm}^{2}\right)$, length and the maximum width of flag leaf was measured and the area was calculated using the following formula suggested by Muller (1991) as Flag leaf area $=$ leaf length $\times$ maximum leaf width $\times$ correction factor (0.74). The mean values of parents and $F_{1 \mathrm{~s}}$ cross combinations were used for the estimation of heterosis over standard check. Analysis of combining ability was carried out according to Method II, Model I of Griffing (1956). The percent increase or decrease of $F_{1}$ hybrids over standard check was calculated by using the formulae of Fonseca and Patterson (1968).

$$
\begin{aligned}
& \text { Standard heterosis }(\%) \quad \frac{F_{1}-S C}{S C} \times 100 \\
& F_{1}=\text { Mean value of } F_{1} \text { hybrid, } S C=\text { Mean value of stand- } \\
& \text { ard check }
\end{aligned}
$$

\section{RESULTS AND DISCUSSION}

Analysis of variance: The general combining ability has been equated with additive gene action and specific combining ability with non-additive gene action (Griffing 1956). The analysis of variance (ANOVA) for combining ability (Table 1) showed that mean square due to general combining ability (GCA) and specific combining ability (SCA) was highly significant for all the 12 traits (days to $50 \%$ flowering, days to maturity, plant height, panicle length, productive tillers, number of branches per panicle, number of grains per panicle, flag leaf area, 1000 grain weight, biological yield, grain yield and harvest index) indicating that both additive and non additive gene effects are responsible for the expression of these traits. The estimated value of $\delta^{2} \mathrm{~g}$ was higher than $\delta^{2}$ s for days to 50 $\%$ flowering, days to maturity, plant height, panicle length, productive tiller, number of grains per panicle, flag leaf area, 1000 grain weight, biological yield, grain yield per and harvest index which indicated the predominance of additive gene action same as the ratio of $\left(\delta^{2} \mathrm{~g} / \delta^{2} \mathrm{~s}\right)$ were found more than unity for all the traits except number of branches per panicle could be demonstrated that this trait was governed by nonadditive gene action. The magnitude of additive variance was higher than non additive variance for all the traits except number of branches per panicle. The value of average degree of dominance $\left(\delta^{2} \mathrm{~g} / \delta^{2} \mathrm{~s}\right)^{1 / 2}$ showed over

\begin{tabular}{|c|c|c|c|c|c|c|c|}
\hline Character & $\operatorname{GCA}(\mathrm{d} f=9)$ & $\operatorname{SCA}(d \mathrm{f}=45)$ & Error $(d \mathrm{f}=108)$ & $\delta^{2} g$ & $\delta^{2} s$ & $\delta^{2} g / \delta^{2} s$ & $\left(\delta^{2} g / \delta^{2} s\right)^{1 / 2}$ \\
\hline Days to $50 \%$ flowering & $91.83 * *$ & $0.88 * *$ & 0.14 & 7.64 & 0.74 & 10.28 & 3.20 \\
\hline Days to maturity & $20.51 * *$ & 0.12 & 0.11 & 1.70 & 0.01 & 212.58 & 14.85 \\
\hline Plant height & $1332.38 * *$ & $0.81 * *$ & 0.29 & 111.00 & 0.52 & 212.56 & 14.57 \\
\hline Panicle length & $16.60 * *$ & $0.24 * *$ & 0.02 & 1.38 & 0.22 & 6.04 & 2.45 \\
\hline Productive tillers & $26.42 * *$ & $0.48 * *$ & 0.12 & 2.19 & 0.35 & 6.00 & 2.45 \\
\hline Branches per panicle & $2.23 * *$ & $0.69 * *$ & 0.15 & 0.17 & 0.53 & 0.32 & 0.56 \\
\hline Grains per panicle & $3683.83 * *$ & $67.13 * *$ & 3.43 & 306.69 & 63.69 & 4.81 & 1.04 \\
\hline Flag leaf area & $23.91 * *$ & $2.27 * *$ & 0.50 & 1.95 & 1.77 & 1.10 & 1.04 \\
\hline 1000 grain weight & $5.81 * *$ & $0.45 * *$ & 0.16 & 0.47 & 0.28 & 1.63 & 1.27 \\
\hline Biological yield & $880.06 * *$ & $1.45 * *$ & 0.23 & 73.31 & 1.21 & 60.15 & 7.75 \\
\hline Harvest index & $155.08 * *$ & $1.04 * *$ & 0.11 & 12.91 & 0.93 & 13.88 & 3.72 \\
\hline Grain yield & $127.41 * *$ & $0.29 * *$ & 0.08 & 10.61 & 0.21 & 49.31 & 7.02 \\
\hline
\end{tabular}
dominance for all the 12 traits except number of

Table 1. Analysis of variance for combining ability of grain yield and agromorphological traits in rice.

* Significant at $5 \%$ probability level, ** Significant at $1 \%$ probability level 
branches per panicle. Singh et al., (2013) reported similar results for days to $50 \%$ flowering, days to maturity, plant height, productive tillers, 1000 grain weight and grain yield in rice at different location of India.

General combining ability: In the present investigations, it was observed that none of the parents was found as good general combiner for all the 12 traits under study. The magnitude and direction of combining ability effects provides the guidelines for the utilization of parents in breeding programme. The performance of parents in respect of general combining ability effects (Table 2), CSR 13 for days to $50 \%$ flowering, days to maturity, plant height, panicle length, grains per panicle, biological yield, harvest index; CSR 30 for branches per panicle, grains per panicle, flag leaf area, 1000 grain weight, harvest index; Vallabh Basmati 21 for days to $50 \%$ flowering, days to maturity, panicle length, branches per panicle, grains per panicle, flag leaf area, 1000 grain weight, biological yield, harvest index; Pusa basmati 1 for days to $50 \%$ flowering, days to maturity, plant height, grains per panicle; Vallabh Basmati 22 for plant height, productive tillers, branches per panicle, biological yield; MAUB 57 for plant height, productive tillers, 1000 grain weight, biological yield; Pusa 1121 for days to $50 \%$ flowering, panicle length, flag leaf area, 1000 grain weight; Basmati 370 for days to maturity, panicle length, productive tillers, flag leaf area, biological yield; Pusa 1401 for days to $50 \%$ flowering, days to maturity, plant height, panicle length, number of grains per panicle and CSR 10 for days to $50 \%$ flowering, days to maturity, plant height, 1000 grain weight and harvest index showing good favorable GCA effects. Four parents CSR 13, CSR 30, Vallabh Basmati 21 and Pusa Basmati 1 were found good general combiners for grain yield and some other major yield contributing traits. It is clear from above results that some parents are good general combiner for more than one trait. Therefore, these parents can be used in crossing programme in the improvement of rice crop.

Our findings indicated that Pusa Basmati 1 and CSR 13 may be exploited for earliness, short plant height and higher grain yield whereas Vallabh Basmati 21 had good general combining ability effects for earliness and higher grain yield. Parents CSR 13, CSR 30, Vallabh basmati 21 and Pusa basmati 1 had significant general combining ability effects for grain yield and other component traits. (Griffing 1956) reported that high GCA effects are mostly due to additive gene effects or additive $\times$ additive interaction effects therefore, breeders may utilize the good general combiners in specific breeding programme for improvement of grain yield in rice. Hence, these good general combiners may be extensively used in future for hybrid rice breeding programme. Similar findings were also reported by Roy and Senapati (2012), Kumari et al. (2014), Devi and Lal (2015), Bhati et al. (2015) and

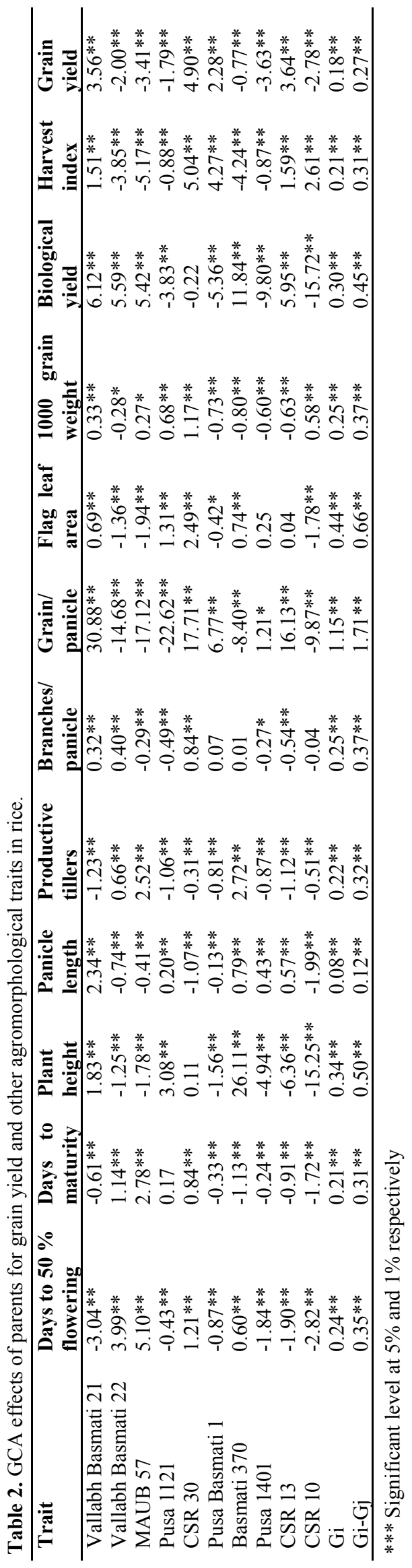




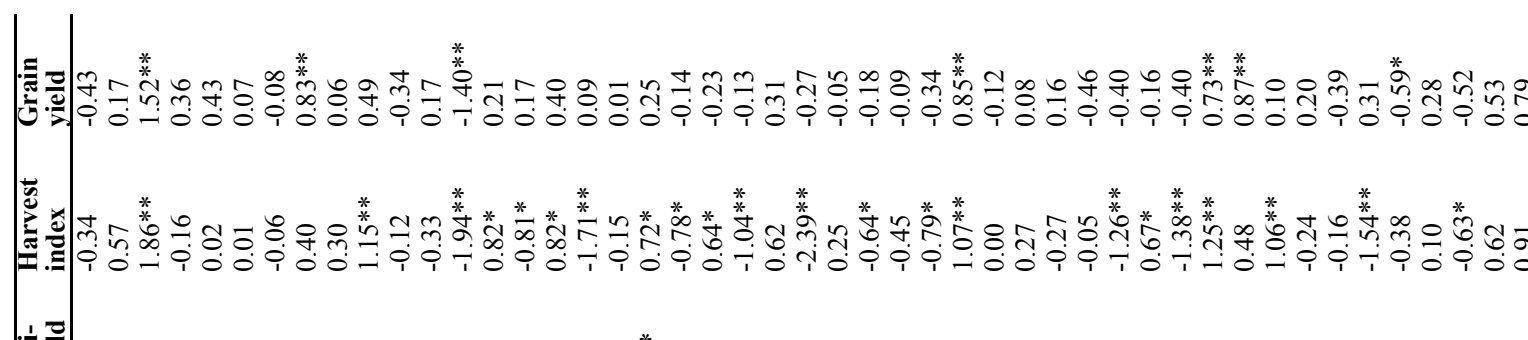

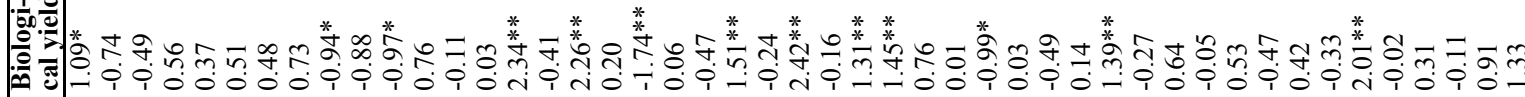

:

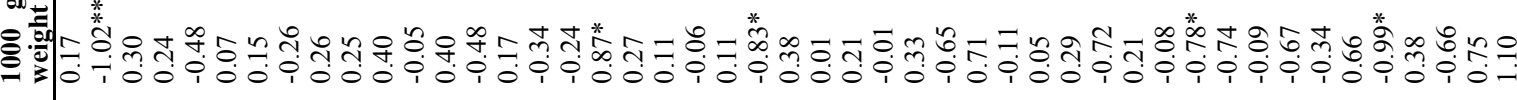

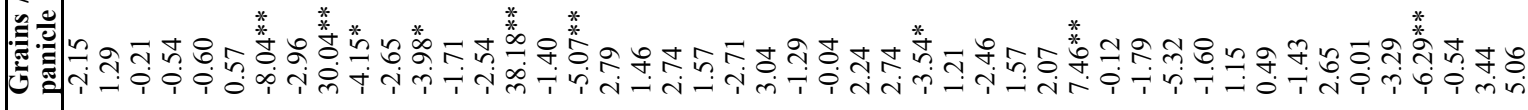
昰

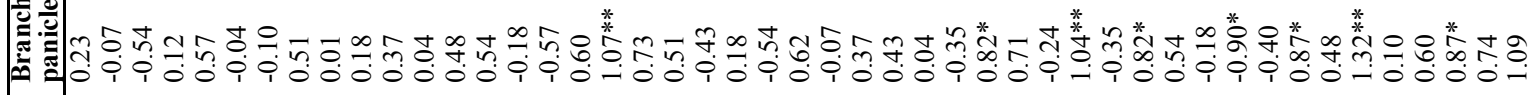

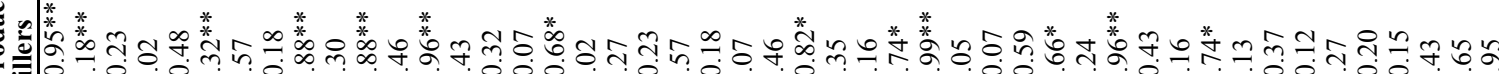

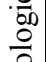

छ

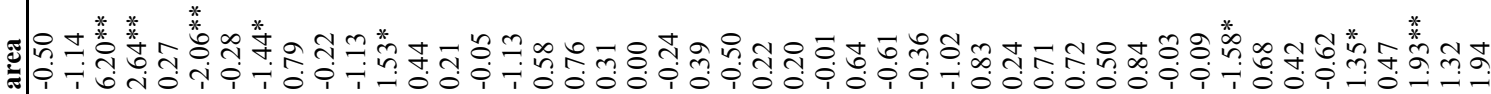

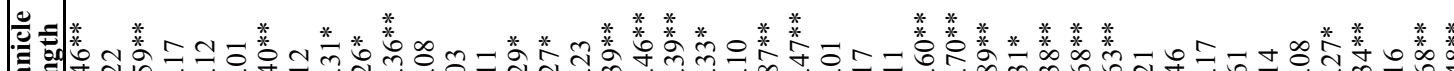

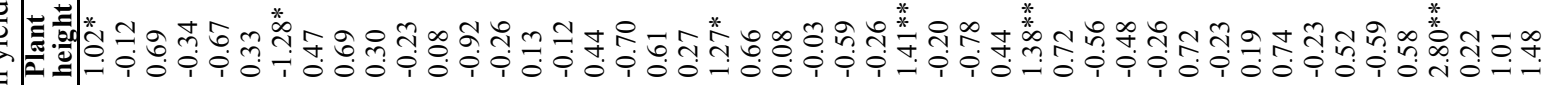

(3)

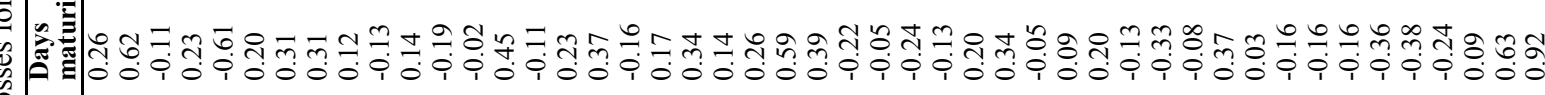

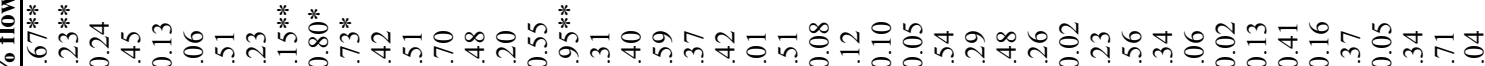


Table 4. Promising hybrids for grain yield and other agromorphological traits in rice.

\begin{tabular}{|c|c|c|c|c|}
\hline \multirow{2}{*}{$\begin{array}{l}\text { Heterotic crosses } \\
\text { Vallabh Basmati } 21 \\
\text { x CSR } 30\end{array}$} & \multirow{2}{*}{$\begin{array}{l}\text { Heterosis over standard } \\
\text { check for grain yield }\end{array}$} & \multicolumn{2}{|c|}{$\begin{array}{l}\text { GCA effects of par- } \\
\text { ents for grain yield }\end{array}$} & \multirow{2}{*}{$\begin{array}{l}\text { Other agromorphological traits } \\
\begin{array}{l}\text { Panicle length, Flag leaf area, } 1000 \text { grain } \\
\text { weight, Biological Yield }\end{array}\end{array}$} \\
\hline & & $3.56^{* *}$ & $4.90 * *$ & \\
\hline CSR 30 X CSR 13 & $10.76^{* *}$ & $4.90 * *$ & $3.64 * *$ & $\begin{array}{l}\text { Plant height, Panicle length, Flag leaf area, Pro- } \\
\text { ductive tillers, Grains per panicle, Biological } \\
\text { Yield, }\end{array}$ \\
\hline $\begin{array}{l}\text { Vallabh Basmati } 21 \\
\text { x CSR } 13\end{array}$ & $10.43 * *$ & $3.56 * *$ & $3.64 * *$ & $\begin{array}{l}\text { Days to } 50 \% \text { flowering, Panicle length, Biolog- } \\
\text { ical Yield }\end{array}$ \\
\hline $\begin{array}{l}\text { CSR 30 } \quad x \quad \text { Pusa } \\
\text { Basmati } 1\end{array}$ & $8.12 * *$ & $4.90 * *$ & $2.28 * *$ & $\begin{array}{l}\text { Branches per panicle, Grains per panicle, Biolog- } \\
\text { ical Yield, Flag leaf area, Productive tillers, }\end{array}$ \\
\hline $\begin{array}{l}\text { Pusa Basmati } 1 \text { x } \\
\text { CSR } 13\end{array}$ & $6.73 * *$ & $2.28 * *$ & $3.64 * *$ & $\begin{array}{l}\text { Plant height, Panicle length, Productive tillers, } \\
\text { Grains per panicle, Biological Yield, }\end{array}$ \\
\hline $\begin{array}{l}\text { Vallabh Basmati } 21 \\
\text { x Pusa Basmati } 1\end{array}$ & $5.18 * *$ & $3.56 * *$ & $2.28 * *$ & $\begin{array}{l}\text { Days to } 50 \% \text { flowering, Days to maturity, Pani- } \\
\text { cle length, Biological Yield }\end{array}$ \\
\hline
\end{tabular}

**Significant at $1 \%$ level of significance; Standard check: Pusa Basmati 1.

Mallikarjuna et al. (2016) for grain yield and other agromorphological traits in rice crop at different locations of India. The per se performance of parents and their GCA effects were almost in close correspondence with each other for different yield contributing traits which indicated that per se performance of parents could possibly be taken as a criteria for selection of desirable parents in breeding programme for the genetic improvement of rice crop.

Specific combining ability: The significant positive and negative SCA effects were found in $\mathrm{F}_{1} \mathrm{~s}$ generations for grain yield and other agromorphological traits. In the present investigation, none of the crosses revealed good specific combining ability effects for all 12 traits which kept under study (Table 3). Out of 45 crosses, 6 crosses for days to 50 per cent flowering; none of the cross for days to maturity; 6 crosses for plant height, 14 crosses for panicle length, 13 crosses for productive tillers, 8 crosses for branches per panicle, 9 crosses for grains per panicle, 8 crosses for flag leaf area, 5 crosses for 1000 grain weight, 13 crosses for biological yield, 7 crosses for grain yield and 20 crosses for harvest index, which has been exhibiting significant and desirable SCA effects for grain yield and other component traits.

The specific combining ability of a cross is the estimation of the effect of non-additive gene action for a trait and non-additive gene action of a trait is an indicator for the selection of a hybrid combination. Therefore, a highly significant SCA effect is desirable for a successful hybrid breeding programme. In the present study, majority of the cross combinations which showed significant SCA effects involved at least one parent having high GCA effects for yield and its contributing traits. A comparative study of promising cross combinations along with their per se performance, general combining ability effects of the parents for grain yield and also other traits showing desirable SCA effects in the specific crosses could be described in this investigation. It can be seen that all the best specific cross combinations for grain yield were ob- tained either through high $\mathrm{x}$ high or high $\mathrm{x}$ low parental GCA effects. In the present study, positive and significant SCA effects for grain yield was exhibited by five cross combinations namely Vallabh Basmati $21 \mathrm{x}$ Pusa 1121, Pusa 1121 x CSR 13, Pusa Basmati 1 x CSR 13, Pusa Basmati 1 x Pusa 1401 and Vallabh Basmati 21 x CSR 13. Most of the crosses having significant SCA effects also having high per se performance for most of the traits. The cross combination having significant SCA effects but failed to record high per se performance results from parents with low x low parental GCA effects. The present findings also indicates that crosses having significant SCA effects recorded highest per se performance, where either of the parent involved in combination have high GCA effects. Estimates of specific combining ability effects revealed that the cross combinations Vallabh Basmati $21 \times$ Pusa 1121 exhibiting positive SCA effects for grain yield with positive effects for productive tillers, flag leaf area, harvest index and Pusa 1121 x CSR 13 for grain yield, panicle length, productive tillers and harvest index. The high SCA effects and highest per se performance was noted in Vallabh Basmati 21 x Pusa 1121, Pusa 1121 x CSR 13 and Pusa Basmati 1 x CSR 13 cross combinations, it is interested to note that the best crosses for SCA effects were also having high per se performance. Out of five promising crosses, only Pusa basmati 1 x CSR 13 have both parents with good $\mathrm{x}$ good GCA effects for grain yields. Good x good GCA effects could be due to additive gene action which is fixable in nature and may be exploited further using pedigree method of breeding for the development of pure lines. The other crosses, Vallabh Basmati $21 \mathrm{x}$ Pusa 1121 and Pusa 1121 x CSR 13 had high SCA effects for grain yield and resulted from good $\mathrm{x}$ poor or poor x good GCA effects. This might be due to additive $\mathrm{x}$ dominance type of gene interaction with epistasis gene action and non fixable genetic components for grain yield. Similar findings were also earlier reported by Roy and Senapati (2012), Kumari et al. (2014), Devi and Lal (2015) and Mallikarjuna et al. (2016) for 
grain yield and other agromorphological traits in rice crop at different locations of India. To obtain early desirable segregants, the appropriate breeding method would be biparental mating reciprocal recurrent selection. The crosses involved at least one parent with good GCA effects indicating that presence of additive $\mathrm{x}$ additive or additive $\mathrm{x}$ dominance interaction, while remaining crosses involved poor combiners suggesting the epistatic gene action which could be mainly due to genetic diversity in the form of heterozygous loci Ram et al. (1998). It appeared that crosses with one good and one poor general combiner would produce hybrids with good specific combinations.

The scope of exploitation of hybrid vigour for higher yield and the associated problems have been discussed earlier by Saravanan et al. (2006) in rice crop. Best exploitation of heterosis for non-additive gene action has been done through the development of hybrid rice using cytoplasmic genetic male sterility system in China. In conventional breeding, which operates on additive gene action and additive $\mathrm{x}$ additive type of gene interactions, the breeder's interest is in the recombinants exhibiting transgressive segregants, which may produce promising genotypes as commercial cultivars in self-pollinated crops including rice.

Standard heterosis: It was observed that significant positive heterosis exhibited by six promising crosses over standard check for grain yield and other agromorphological traits is presented in (Table 4). Standard heterosis for grain yield ranged from -34.75 to 12.78 per cent. The promising cross combinations showing significant positive heterosis over the standard check were Vallabh Basmati 21 x CSR 30, CSR 30 x CSR 13, Vallabh Basmati $21 \times$ CSR 13, CSR 30 x Pusa Basmati 1, Pusa Basmati 1 x CSR 13 and Vallabh Basmati 21 x Pusa Basmati 1. These crosses expressed significant positive heterosis over standard check for grain yield and some other component traits indicating that these crosses have the capability for hybrid rice production. These crosses having the parents with good general combining ability effects for grain yield. Similar findings were also reported by Kumari et al. (2014) and Sarvan et al. (2016) for grain yield, panicle length, productive tillers per plant, days to maturity, days to flowering, plant height in rice crop in Varanasi (India). All six promising crosses for higher grain yield having both parents with good $\mathrm{x}$ good GCA effects could be due to additive gene action which is fixable in nature and may be exploited further using pedigree method of breeding for the development of pure lines in rice crop.

\section{Conclusion}

The superior performance for all traits was not expressed in a single cross combination. However, different crosses were found to be superior for different traits. On the basis of above findings, it was concluded that all the traits were governed by additive gene action. The best combinations mostly involved good $\mathrm{x}$ good and good $\mathrm{x}$ poor general combiners for the traits under study. The cross Pusa basmati 1 x CSR 13 having both parents with good $\mathrm{x}$ good GCA effects for grain yield. Good x good GCA effects could be due to additive gene action which is fixable in nature and can be improved by pedigree breeding and selection can be postponed to later generations. Whereas the crosses Vallabh Basmati 21 x Pusa 1121 and Pusa 1121 x CSR 13 had high SCA effects for grain yield and resulted from good $\mathrm{x}$ poor or poor $\mathrm{x}$ good GCA effects. This might be due to additive $\mathrm{x}$ dominance type of gene interaction with epistasis gene action and non fixable genetic components for grain yield. The most appropriate breeding method for the exploitation of non additive gene action will be heterosis breeding. The six best cross combinations (Vallabh Basmati 21 x CSR 30, CSR $30 \times$ CSR 13, Vallabh Basmati $21 \times$ CSR 13, CSR 30 x Pusa basmati 1, Pusa basmati 1 x CSR 13 and Vallabh Basmati $21 \times$ Pusa basmati 1) had significant standard heterosis for grain yield and other component traits. The cross which shows significant standard heterosis is highly suitable for commercial exploitation of heterosis in rice crop.

\section{REFERENCES}

Bhati, S., Pandey, D. P. and Singh, D. (2015). Combining ability and heterosis for yield and its component traits in rice [Oryza sativa (L.)]. Electronic Journal of Plant Breeding, 6(1): 12-18

Devi, B. and Lal, G. M. (2015). Combining ability analysis for yield and yield components in rice (Oryza sativa L.). Electronic Journal of Plant Breeding, 6(2): 360-365

Fonseca, S. and Patterson, E.L. (1968). Hybrid vigour in seven parent diallel cross in common winter wheat (Triticum aestivum L.). Crop Sciences, 8: 85-95

Griffing, B. (1956a). Concept of general and specific combining ability in relation to diallel crossing systems. Australian Journal of Biological Sciences, 9: 463-493

Hayman, B.I. (1954). The theory and analysis of diallel crosses. Genetics, 39(6):789-809

Kumari, P., Jaiswal, H. K. and Waza, S. A. (2014). Combining ability and heterosis for yield, its component traits and some grain quality parameters in rice (Oryza sativa L.). Journal of Applied and Natural Science, 6(2):495506

Mallikarjuna, B.P., Shivakumar, N. and Kukanur, S. (2016). Combining ability analysis in newly developed rice (Oryza sativa L.) hybrids. Environment and Ecology, 34 (1A): 400-404

Muller, J. (1991). Determining leaf surface area by mean of linear measurements in wheat and triticale. Archiv Fuchtungsforschung, 21(2): 121-23

Panse, V. G. and Sukhatme, P. V. (1967). Statistical methods of agricultural workers. 2nd Endorsement, ICAR Publication, New Delhi, India Pp: 381

Ram, T., Singh, J. and Singh, R.M. (1998). Combining ability for yield and its components in rice. Oryza, 35(3): 
$237-241$

Roy, S.K. and Senapati, B.K. (2012). Combining ability analysis for grain yield and quality characters in rice (Oryza sativa). Indian Journal of Agricultural Sciences, 82(4): 293-303

Saravanan, K., Anbanandan, V. and Kumar, S. (2006). Heterosis for yield and yield components in rice (Oryza sativa L.). Crop Research, 31(2): 242-244
Singh, M.K., Singh, R.P. and Singh, P. (2013). Identification of good combiners in early maturing $\mathrm{x}$ high yielding cultivars of Indica rice (Oryza sativa L.). Bangladesh journal of botany, 42(2): 247-255

Sarvan, T., Jaiswal, H.K., Showkat, A.W. and Kumari, P. (2016). Heterosis for yield and yield attributes in rice (Oryza sativa L.). Journal of Applied and Natural Science, 8(2): 622- 625 